\title{
PENERAPAN COMMUNITY BASED TOURISM (CBT) DALAM PENGEMBANGAN DESA WISATA DI DESA SEKAPUK KECAMATAN UJUNGPANGKAH KABUPATEN GRESIK
}

\author{
${ }^{1}$ Maslakhatun Niswah, ${ }^{2}$ Tukiman \\ 1,2 Program Studi Administrasi Publik Fakultas IImu Sosial dan IImu Politik \\ Universitas Pembangunan Nasional "Veteran" Jawa Timur \\ niswahmaslakhatun@gmail.com, tukiman upnjatim@yahoo.com \\ Kota Surabaya, Jawa Timur, Indonesia
}

\begin{abstract}
The COVID-19 pandemic has had a significant impact in various fields, especially in the tourism sector which also has an impact on the country's economy. The central and local governments are currently doing various methods, including the Sekapuk Village Government. In the midst of the current pandemic, Sekapuk Village has succeeded in increasing village income as a source of economic resilience from tourism. Sekapuk Village has also achieved various achievements. This is inseparable from the support from the community. The purpose of this research is to see the application of the principles of Community Based Tourism (CBT) in the Development of Tourism Villages in Sekapuk Village, Ujungpangkah District, Gresik Regency. This type of research used in this research is descriptive qualitative. The results of this study indicate that the implementation of CBT in Sekapuk Village has not been implemented as a whole. In the planning principle, the community has not played an active role. Then on the principle of implementation, the community has played an active role and participated in tourism ownership. Furthermore, the impact and benefits have been felt by the community significantly.
\end{abstract}

\section{Keywords: Community Based Tourism, Tourism Village Development; Village}

\begin{abstract}
Abstrak
Pandemi COVID-19 membawa dampak yang signifikan di berbagai bidang, khususnya di bidang pariwisata yang juga berdampak pada perekonomian negara. Bermacam cara sedang dilakukan pemerintah pusat maupun pemerintah daerah, termasuk Pemerintah Desa Sekapuk. Ditengah pandemi saat ini Desa Sekapuk berhasil meningkatkan pendapatan desa sebagai salah satu sumber ketahanan ekonomi yang berasal ari wisata, berbagai prestasijuga telah diraih oleh Desa Sekapuk. Hal ini tidak terlepas dari dukungan dari masyarakat. Tujuan dari dilakukannya penelitian ini yaitu agar melihat penerapan prinsip Community Based Tourism (CBT) dalam Pengembangan Desa Wisata di Desa Sekapuk Kecamatan Ujungpangkah Kabupaten Gresik. Jenis penelitian yang digunakan dalam penelitian ini yaitu deskriptif kualitatif. Hasil penelitian ini menunjukkan bahwa penerapan CBT di Desa Sekapuk belum diterapkan secara keseluruhan. Pada prnsip perencanaan masyarakat belum berperan secara aktif. Kemudian pada prinsip implementasi masyarakat sudah berperan secara aktif dan ikut serta dalam kepemilikan wisata. Selanjutnya pada dampak dan manfaat sudah dirasakan masyarakat dengan signifikan.
\end{abstract}

Kata Kunci: Community Based Tourism, Desa; Pengembangan Desa Wisata

Open Access at:http://ojs.uho.ac.id/index.php/PUBLICUHO/index

Journal Publicuho is licensed under a Creative Commons Attribution 4.0 International License. 


\section{PENDAHULUAN}

Pertumbuhan ekonomi adalah faktor yang menjadi perhatian bagi suatu negara. Pertumbuhan ekonomi Indonesia oleh saat ini mengalami kemerosotan yang cukup signifikan. Hal ini terjadi akibat pandemic Corona Virus Diseases 2019 atau yang lebih dikenal COVID-19. Virus tersebut melanda di berbaga negara dunia. Seperti yang dimuat dalam kompas.com bahwa International Monetary Fund (IMF) memproyeksikan bahwa perekonomian global akan mengalami penurunan lebih parah dari yang sudah diprediksi yang sebelumnya. Sebelumnya IMF mengatakan bahwa pada tahun 2020 ini tingkat ekonomi dunia akan mengalami krisis terburuk sejak krisis besar pada tahun 1930-an.

Indonesia adalah negara yang terpapar COVID-19 yang sedang berupaya untuk memulihkan ekonomi negara. Upaya tersebut dilakukan melalui bidang pariwisata. Karena melihat Indonesia memiliki potensi alam dan keindahan yang sangat besar dari segi daratan lautan, dan berbagai sumber daya alam serta kekayaan budaya.

Pembangunan pariwisata di Indonesia sedang gencar dikembangkan di Indonesia, melihat sektor ini juga terdampak COVID-19. Lestari, (2019) berpendapat bahwa Pengembangan Pariwisata merupakan aktivitas yang dilakukan dalam upaya mengembangkan dan memajukan bidang pariwisata. Kemudian menurut Yoeti dikutip oleh Elfianita, (2016) berpendapat bahwa pengembangan pariwisata adalah upaya dalam menciptakan destinasi wisata. Dari teori diatas dapat dikemukakan bahwa pembangunan pariwisata merupakan suatu upaya membangun dan memperbaiki dalam sektor pariwisata guna dapat menarik wisatawan untuk datang. Pembangunan pariwisata harus tetap dlakukan karena destinasi tidak bisa lepas dari proses evolusi wisata agar masyarakat tetap tertarik untuk datang meskipun destinasi tersebut dirasa cukup lama, oleh karena itu diperlukan inovasi-inovasi atau peremajaan destinasi.

Upaya pemulihan tersebut dilakukan Indonesia untuk meningkatkan pertumbuhan ekonomi Indonesia yang sedang mengalami penurunan. Pembangunan pariwisata adalah proses pembangunan dan perbaikan dibidang pariwisata yang memiliki tujuan peningkatan kemampuan manusia dalam meningkatkan kesejahteraan masa depannya (Rahmi, 2016). Menurut Undang-Undang Nomor 25 Tahun 2000 Tentang Pembangunan Nasional bahwa Pembangunan Pariwisata bertujuan untuk: 1) Meningkatkan produk dan kualitas pariwisata; 2) Berbasis pada pemberdayaan masyarakat; 3) Mengembangkan serta memperluas pasar wisata. Berbagai wilayah di Indonesia baik kota maupun pedesaan mulai berlomba-lomba untuk melakukan pengembangan potensi masing-masing agar dapat digunakan sebagai wisata sehingga mampu membantu meningkatkan perekonomian dan pendapatan masyarakat maupun pendapatan negara serta dengan adanya pengembangan pariwisata mampu membuka kesempatan kerja. Dampak lain yang ditimbulkan dari pengembangan 


\section{Journal Publicuho}

ISSN2621-1351 (online), ISSN 2685-0729 (print)

Volume 4 Number 2 (May-July), (2021)pp. 591-601

Accredited SINTA SK.NOMOR 28/E/KPT/2019

Open Access at:http://ojs.uho.ac.id/index.php/PUBLICUHO/index

DOI: 10.35817/jpu.v4i2.18232

pariwisata dalam kehidupan masyarakat seperti adanya kesadaran masyarakat akan potensi yang dimiliki, kesadaran akan hidup bersih, serta mampu meningkatkan rasa kecintaan masyarakat terhadap wilayahnya. Sulistiyani dikutip oleh Ahsani, (2013) berpendapat bahwa kondisi diatas diumpamakan sebagai dayung bersambut segala sektor mulai dikembangkan salah satunya adalah munculnya berbagai macam konsep desa wisata.

Desa wisata menurut Prabowo, (2016) adalah kawasan pedesaan yang memiliki berbagai macam wisata yang dikemas sedemikian rupa sehingga dapat menarik wisatawan untuk berkunjung dan menetap, serta menghabiskan waktu berhari-hari. Dalam upaya mengembangkan desa wisata terdapat beberapa model dalam pengembangannya. Kemudian Nuryanty dikutip oleh Pantiyasa (2018) berpendapat bahwa Desa wisata merupakan salah satu objek pembangunan pariwisata yang memiliki potensi di lingkup daerah. Dari beberapa teori diatas dapat diketahui bahwa desa wisata yaitu kawasan pedesaan yang menawarkan sebuah wisata baik wisata alam maupun wisata lainnya yang mencerminkan keaslian desa tersebut guna dapat meningkatkan kesejahteraan masyarakat lokal dan kepedulian terhadap lingkungan sekitar. Dengan adanya model-model dalam tersebut dapat dijadikan pedoman dalam mengembangkan desa wisata yang diharapkan dapat meningkatkan perekonomian dan pendapatan negara.

Community Based Tourism (CBT) adalah model dalam mengembangkan desa wisata sebagai salah satu upaya untuk meningkatkan perekonomian negara melalui bidang pariwisata. Purmada \& Hakim (2016) berpendapat bahwa CBT adalah konsep pengembangan desa yang mengutamakan partisipasi aktif masyarakat agar dapat memberikan kesejahteraan bagi masyarakat dan lingkungan sekitar. Menurut Drake dikutip oleh Satrio \& Sabana (2018) keterlibatan masyarakat local sebagai komponen utama dari prinsip pengembangan Community Based Tourism yang dapat dilaksanakan dengan beberapa tahap yaitu sebagai berikut:

1. Perencanaan: Memposisikan masyarakat menjadi subjek aktif yang memiliki peran dalam perencanaan. Pada prinsip perencanaan ini dilakukan dengan menempatkan masyarakat sebagai subjek aktif yang berupa mampu mengidentifikasi fenomena atau kendala di masyarakat, mengidentifikasi potensi wisata, serta mengembangkan alternatif strategi rencana rencana serta sarana prasarana.

2. Pelaksanaan: Memposisikan masyarakat menjadi subjek aktif yang memiliki peran dalam pelaksanaan pengembangan wisata. Hal ini berbentuk partisipasi aktif dalam pelaksanaan secara langsung pada pengelolaan wisata.

3. Dampak dan manfaat yang didapatkan: Semua yang telah dikembangkan melalui wisata harus memiliki dampak dan manfaat yang diterima oleh masyarakat. Hal ini 
dapat tercapai melalui peran dan posisi masyarakat yang mendapatkan nilai manfaat yang signifikan, baik secara ekonomi maupun sosial budaya, yang akan berdampak pada peningkatan kesejahteraan ekonomi masyarakat lokal

Desa Sekapuk adalah desa di Kabupaten Gresik yang sedang berupaya melakukan pengembangan di sektor pariwisata. Desa Sekapuk memiliki potensi alam yang patut dilestarikan dan saat ini sudah dijadikan sebagai obyek wisata baru yaitu Selo Tirto Giri (SETIGI) oleh pemerintah desa mengingat lokasi yang sangat strategis dan memiliki value untuk meningkatkan perekonomian desa. Lebih lanjut, SETIGI merupakan wisata bukit kapur yang dibangun pemerintah Desa Sekapuk dalam upaya pelestarian lokasi bekas galihan tambang dan tempat pembuangan sampah dengan harapan dapat menyejahterakan warga Desa Sekapuk.

Berdasarkan hasil Indeks Desa Mandiri (IDM) yang dilakukan oleh Kementerian Desa, bahwa status Indeks Desa Mandiri (IDM) Desa Sekapuk pada tahun 2017 mendapatkan nilai 0.5350, dimana nilai tersebut menunjukkan angka dibawah rata-rata dan tergolong desa tertinggal. Namun, sejak pemilihan kepada desa baru, dan terpilihnya Abdul Halim sebagai Kepala Desa Sekapuk yang baru mampu membawa desa tersebut berkembang dengan pesat dan tergolong desa mandiri dengan IDM0,8835 pada tahun 2020. Berbagai penghargaan telah diterima oleh Desa Sekapuk diantaranya dianugerahkan sebagai desa wsisata oleh Dinas Pariwisata dan Kebudayaan Kabupaten Gresik Tahun 2020, kemudian Indonesian The Most Potential Destination Awards 2020 oleh Seven Media Asia.

Dengan PAD mencapai miliaran rupiah tersebut, pemerintah desa Sekapuk membuat Program-program seperti pemberian beasiswa dengan jenis beasiswa sebagai berikut: 1) Bagi Warga Desa Sekapuk dengan status Yatim/Piatu dimana beasiswa ini diperuntukkan pada warga desa kelas 1 (SD) sampai dengan kelas 9 (SMP); 2) Bagi Warga Desa Sekapuk yang Hafidz/Hafidzah dimana beasiswa ini diperuntukkan pada jenjang Strata 1 (S1) yang hafal Al-Qur'an. Keberhasilan Desa Sekapuk tidak hanya terlihat dengan bantuan beasiswa saja, namun desa ini juga memiliki aset bergerak seperti yang dimuat dalam artikel katadesa.com bahwa asset tersebut yang 5 buah unit mobil operasional dan puluhan sepeda listrik. Dimana dari 5 mobil yang ada, hanya satu mobil yang menggunajan dana desa. Empat mobil lainnya dibeli dari pendaoatan unit usaha yang dikelola oleh Desa Sekapuk. Jenis mobilnya yaitu Alphard digunakan pemerintah desa, Expander digunakan BUMDesa, Grand Livina digunakan PKK, dan Mazda Double Cabin untuk wisata Setigi

Jumlah wisatawan yang berkunjung ke Desa Sekapuk semakin meningkat setiap bulannya. Setelah wisata diliburkan akibat pandemi, jumlah wisatawan justru semakin meningkat karena wisata Desa Sekapuk dinilai memiliki potensi wisata yang istimewa. Dengan segala keunikan dan keunggulannya sehingga menjadi sesuatu yang sangat menarik bagi wisatawan. Kenaikan jumlah pengunjung pada tahun 2020 yang sedang 


\section{Journal Publicuho}

ISSN2621-1351 (online), ISSN 2685-0729 (print)

Volume 4 Number 2 (May-July), (2021)pp. 591-601

Accredited SINTA SK.NOMOR 28/E/KPT/2019

Open Access at:http://ojs.uho.ac.id/index.php/PUBLICUHO/index

DOI: 10.35817/jpu.v4i2.18232

pandemi saat ini merupakan hal positif, karena dapat meningkatkan pendapatan desa yang ada guna sebagai salah satu sumber ketahanan ekonomi Desa Sekapuk di masa pandemi saat ini.

Keberhasilan yang dicapai oleh Desa Sekapuk saat ini, tidak terlepas dari dukungan dan partisipasi dari masyarakat. Sehingga, peneliti tertarik untuk mengetahui bagaimana penerapan Community Based Tourism (CBT) yang dapat membuat desa ini dapat berkembang dengan signifikan. Atas dasar tersebut, peneliti tertarik dalam melihat penerapan Community Based Tourism (CBT) di Desa Sekapuk. Kemudian penelitian ini memiliki untuk mengetahui penerapan prinsip Community Based Tourism (CBT) dalam Pengembangan Desa Wisata di Desa Sekapuk Kecamatan Ujung Pangkah Kabupaten Gresik

\section{METODOLOGI}

Dalam penelitian ini penulis menggunakan jenis penelitian yang bersifat deskriptif dengan pendekatan kualitatif dengan tujuan menggambarkan secara sistematis mengenai karakteristik maupun fakta objek dan subjek yang sedang diteliti secara tepat dan mendalam terhadap objek penelitian. Penelitian ini mendeskripsikan mengenai Penerapan Community Based Tourism (CBT) dalam Pengembangan Desa Wisata di Desa Sekapuk Kecamatan Ujungpangkah Kabupaten Gresik. Menurut Sugiyono (2018:224) menjelaskan bahwa teknik pengumpulan data adalah langkah proses utama dalam penelitian, hal ini karena tujuan utama dari penelitian adalah yaitu memperoleh data. Sumber data yang didapatkan penelitian ini berasal dari data primer dan sekunder. Data primer penelitian ini berasal dari key informan atau informan kunci terkait penelitian ini. Kemudian data sekunder berasal dari dokumen pendukung yang berkaitan mengenai penelitian ini.

Kemudian penulis dalam penelitian ini menggunakan teknik pengumpulan data berupa wawancara, observasi, serta dokumentasi yang dianalisis menggunakan analisis data interaktif dari Miles dan Huberman dikutip oleh Sugiyono (2018:246) bahwa di dalam analisis data memiliki 4 (empat) aliran (flow) aktivitas yang terjadi bersama-sama. Keempat aliran tersebut yaitu pengumpulan data, kondensasi data,penyajian data, serta penarikan kesimpulan dan verifikasi.

\section{HASIL DAN PEMBAHASAN}

\section{Gambaran Umum Desa Sekapuk Kecamatan Ujungpangkah Kabupaten Gresik}

Desa Sekapuk termasuk ke dalam wilayah Kecamatan Ujungpangkah Kabupaten Gresik yang lokasinya berada di sebelah utara Ibukota Kabupaten Gresik. Desa Sekapuk berbatasan dengan wilayah lain. Sebelah utara Desa Sekapuk adalah Desa Gosari Kecamatan Ujungpangkah. Sebelah selatan Desa Sekapuk adalah Desa Daudo Kecamatan Panceng. Sebelah timur Desa Sekapuk adalah Desa Bolo/Wadeng Kecamaan 
Ujungpangkah, dan sebelah barat Desa Sekapuk adalah Desa Wotan Kecamatan Panceng. Jumlah Penduduk Desa Sekapuk sebanyak 4.673 orang, jumlah Laki - laki sebanyak 2.324 orang dan Perempuan sebanyak 2.349 orang. Mayoritas penduduk Desa Sekapuk beragama muslim atau seluruhnya menganut agama Islam Desa Sekapuk memiliki luas wilayah sebanyak 3,13\% dari total luas wilayah Kecamatan Ujungpangkah yaitu sebesar 2,97 $\mathrm{km}^{2}$ dari $94,82 \mathrm{~km}^{2}$.

\section{Perencanaan}

Perencanaan dalam Penerapan Community Based Tourism (CBT) berarti memposisikan masyarakat menjadi subjek aktif yang memiliki peran dalam perencanaan. Pada prinsip perencanaan ini dilakukan dengan menempatkan masyarakat sebagai subjek aktif yang berupa mampu mengidentifikasi fenomena atau kendala di masyarakat, mengidentifikasi potensi wisata, serta mengembangkan alternatif strategi rencana rencana serta sarana prasarana. Pertama, berkaitan dengan aspek peran masyarakat dalam perencanaan wisata di Desa Sekapuk bahwa masyarakat berperan sebagai "subjek pendukung" diawal perencanaan pengembangan wisata karena terlibat melalui gotongroyong yang diarahkan oleh RTdan RW setempat, segala kebijakan perencanaan dilakukan secara langsung oleh Kepala Desa Sekapuk. Sehingga dapat dikatakan bahwa masyarakat di Desa Sekapuk belum memiliki peran secara aktif dalam proses perencanaan pengembangan wisata.

Kedua, berkaitan dengan aspek keterlibatan masyarakat dalam proses pengambilan keputusan bahwa masyarakat diawal perencanaan tidak dilibatkan. Segala keputusan diambil secara langsung oleh Kepala Desa Sekapuk. Namun setelah itu dilakukan rapat rutinan yang dilakukan oleh stakeholder, rt, rw, dan tokoh masyarakat untuk membahas langkah-langkah strategis lanjutan guna dalam pengembangan wisata. Sehingga dapat dikatakan bahwa masyarakat belum terlibat secara aktif dan keseluruhan di awal perencanaan pengembangan wisata, namun saat ini hal tersebut telah diperbaiki.

Ketiga, berkaitan dengan aspek workshop atau pelatihan kepada masyarakat mengenai pengembangan wisata bahwa bahwa terdapat workshop atau pelatihan yang diadakan secara khusus oleh pemerintah desa kepada masyarakat setempat guna mendukung pengembangan wisata. Kemudian terdapat ada minimal 2 orang perwakilan pemuda tiap RT untuk ikut dalam Pokdarwis yang nantinya mengikuti workshop atau pelatihan yang diadakan oleh Dinas Pariwisata Gresik. Sehingga dapat dikatakan bahwa diterapkannya dan diadakannya workshop/pelatihan mengenai pengembangan wisata di Desa Sekapuk.

\section{Implementasi}

Dalam mengkaji studi implementasi sebuah kebijakan publik maka perlu diketahui variabelvariabel atau faktor yang mempengaruhinya. Ada beberapa model implementasi yang dapat digunakan sebagai acuan, diantaranya adalah sebagai berikut; 


\section{Journal Publicuho}

ISSN2621-1351 (online), ISSN 2685-0729 (print)

Volume 4 Number 2 (May-July), (2021)pp. 591-601

Accredited SINTA SK.NOMOR 28/E/KPT/2019

Open Access at:http://ojs.uho.ac.id/index.php/PUBLICUHO/index

DOI: 10.35817/jpu.v4i2.18232

Grindle (1980) yang dilkutip dari (Elwan, L.O.M, 2011:15) dijelaskan bahwa mendekati implementasi kebijakan sebagai suatu proses tindakan-tindakan administratif umum yang perlu diperiksa sampai level program yang spesifik. Keberhasilan atau kegagalan dari suatu kebijakan dapat dilihat dari kapasitasnya untuk menjalankan program sesuai dengan desain semula. Karena itu, implementasi kebijakan secara keseluruhan perlu dilihat dengan mempertanyakan apakah pelaksanaan kebijakan sesuai dengan yang ditentukan. (dalam Elwan.L.O.M, 2011:22). Pengukuran kesesuaian ini dapat dilihat dari dua hal, yaitu: a) Dilihat dari prosesnya, yakni yang dapat diperiksa pada tingkat program yang spesifik dan dana yang dialokasikan, serta b) Dilihat dari hasil yang dicapai oleh implementasinya kebijakan tersebut. Dimensi ini diukur dengan melihat dua faktor, yaitu: a) Dampak atau efeknya pada masyarakat secara individu dan kelompok; dan b) Tingkat perubahan yang terjadi serta penerimaan kelompok sasaran terhadap perubahan yang terjadi.

Lebih lanjut, menurut argumen Grindle (dalam Elwan.L.O.M, 2011: 22) bahwa keberhasilan suatu implementasi kebijakan publik amat ditentukan oleh derajat dapat tidaknya kebijakan itu diterapkan atau implementabilitas (implementability) dari kebijakan tersebut. Implementabilitas ini dapat dilihat dari aspek isi kebijakan (content of policy) dan aspek konteks implementasi kebijakan (contexs of policy implementation). (Supriadin et al., 2020)

Demikian halnya menurut Jones (1991) dalam La Ode Muhammad Elwan, (2011: 18) menjelaskan bahwa Implementasi kebijakan mudah dimengerti secara teoritik dan konseptual, namun tidak senantiasa demikian dalam bentuknya yang kongkrit, karena pelaksanaannya secara nyata bukanlah sesuatu yang mudah (Supriadin et al., 2020)

Implementasi dalam hal ini yaitu berkaitan dengan memposisikan masyarakat menjadi subjek aktif yang memiliki peran dalam pelaksanaan pengembangan wisata. Hal ini berbentuk partisipasi aktif dalam pelaksanaan secara langsung pada pengelolaan wisata. Pertama, berkaitan dengan peran masyarakat dalam pelaksanaan pengembangan wisata terlibat melalui kerja bakti yang berdasarkan informasi dan arahan dari rt dan rw setempat. Sehingga berdasarkan uraian diatas berkaitan dengan aspek peran masyarakat dalam implementasi bahwa dapat dikatakan bahwa masyarakat belum berperan secara aktif dalam implementasi pengembangan wisata di Desa Sekapuk.

Kedua, berkaitan dengan pembagian peran antara masyarakat dan pemerintah desa dapat dikatakan bahwa bahwa tidak ada pembagian pera secara tertulis antara masyarakat secara keseluruhan dan pemerintah desa. Pembagian kerja terjadi saat wisata diberikan dan dilimpahkan kepada BUMDesa untuk dikelola. BUMDesa merekrut pegawai yang berasal dari warga sekapuk sendiri. Bagi warga yang termasuk dalam pengelola wisata itu yang memiliki pembagian kerja sesuai bidang masing-masing. Masyarakat secara keseluruhan berperan dalam menjaga kelestarian dan kebersihan desa. Sedangkan 
perangkat desa melakanakan tugasnya sesuai dengan tugas pokok dan fungsi masingmasing jabatan. Kemudian berkaitan dengan sistem evaluasi kinerja masyarakat dan pemerintah desa dilakukan rapat rutinan setiap tanggal 2 di awal bulan yang dihadiri oleh stakeholder, RT, RW dan tokoh masyarakat. Evaluasi juga dilakukan secara online dengan mengadakan pengaduan keluhan oleh masyarakat. Sehingga berdasarkan uraian diatas berkaitan dengan aspek pembagian peran masyarakat dan pemerintah desa dalam fokus implementasi sudah diterapkan dengan baik dalam implementasi pengembangan wisata di Desa Sekapuk

Selanjutnya berkaitan dengan kepemilikan wisata, masyarakat turut serta memiliki wisata tersebut, karena dalam pembangunan dan pengembangan wisata dana secara keseluruhan berasal dari masyarakat. Kepemilikan tersebut berupa obligasi saham yang dilakukan oleh masyarakat dan dikelola oleh BUMDesa Sekapuk.

Hal yang kemudian menjadi problem adalah, bagaimana program atau kegiatan yang sudah direncanakan oleh masyarakat mendapatkan dukungan dari pemerintah khusus pemerintah daerah. Dalam hal ini support sumberdaya dari pemerintah dan masayakat desa menjadi hal mutlak untuk saling mendukung dan memberikan konstribusi kongkrit terhadap kesejahteraan bersama.

Menurut Dwiyanto (2006:56) yang dikutip dari La Ode Muhammad Elwan. (2019) bahwa pemberian pelayanan publik oleh aparatur pemerintah kepada masyarakat (publik) merupakan perwujudan dan fungsi aparatur negara sebagai pelayan masyarakat (abdi), disamping sebagai abdi negara. Dalam konteks ini masyarakatlah sebagai aktor utama (pelaku) pembangunan, sedangkan pemerintah berkewajiban untuk mengarahkan, membimbing serta menciptakan suasana yang menunjang kegiatan-kegiatan dari masyarakat tersebut. Pada kondisi ini aparatur negara dituntut untuk lebih mampu memperbaiki kinerjanya (pelayanan prima) dan diharapkan lebih mampu merumuskan konsep atau menciptakan iklim yang kondusif, sehingga sumber daya pembangunan dapat menjadi pendorong percepatan terwujudnya masyarakat yang mandiri dan sejahtera. Pelayanan yang telah menunjuk kepada aturan formal dianggap telah memenuhi sendisendi pelayanan yang baik dan aparat pelayanan dianggap telah konsisten dalam menerapkan aturan hukum pelayanan. (Muhammad Elwan, 2019)

\section{Dampak dan Manfaat}

Dampak dan manfaat yang dimaksud dalam hal ini semua yang telah dikembangkan melalui wisata harus memiliki dampak dan manfaat yang diterima oleh masyarakat. Hal ini dapat tercapai melalui peran dan posisi masyarakat yang mendapatkan nilai manfaat yang signifikan, baik secara ekonomi maupun sosial budaya, yang akan berdampak pada peningkatan kesejahteraan ekonomi masyarakat lokal. 


\section{Journal Publicuho}

ISSN2621-1351 (online), ISSN 2685-0729 (print)

Pertama, berkaitan dengan dampak yang dirasakan oleh masyarakat pasca pengembangan wisata di Desa Sekapuk cukup signifikan. Jika dilihat dari perekonomian secara perlahan meningkat bagi warga yang terlibat secara langsung dalam wilayah wisata maupun wrga yang usahannya berada di luar wilayah wisata. Sehingga berdasarkan uraian diatas berkaitan dengan aspek dampak yang diterima masyarakat sudah dirasakan dan meningkat secara signifikan.

Kedua, berkaitan dengan terciptanya lapangan pekerjaan dapat dikatakan bahwa sudah tercipta lapangan pekerjaan yang dihasilkan pasca pengembangan wisata di Desa Sekapuk cukup signifikan. Jika dilihat dari lapangan pekerjaan secara perlahan mampu mengcover pengangguran bagi warga Sekapuk. Masyarakat ikut berjualan aksesoris, kuliner, serta yang lainnya. Sehingga berdasarkan uraian diatas berkaitan dengan aspek terciptanya lapangan pekerjaan sudah dirasakan oleh masyarakat Sekapuk.

Ketiga, berkaitan dengan timbulnya pendapatan masyarakat dapat dikatakan bahwa sudah timbul pendapatan masyarakat yang dihasilkan pasca pengembangan wisata di Desa Sekapuk cukup signifikan. Jika dilihat dari pendapatan masyarakat secara perlahan mampu memperbaiki perekonomian masyarakat sekitar. Sehingga berdasarkan uraian diatas berkaitan dengan aspek timbulnya pendapatan masyarakat sudah dirasakan oleh masyarakat Desa Sekapuk. Ketiga sasaran kajian tersebut sesuai dengan pendapat yang dikemukakan oleh Terencia dikutip oleh Quynh (2020) mendefiniskan bahwa Community Based Tourism (CBT) merupakan wisata yang melalui proses perencanaan, dikembangkan dan dikelola oleh masyarakat untuk masyarakat, dipandu oleh pengambilan keputusan bersama, tanggung jawab, akses, kepemilikan dan manfaat dirasakan secara signifikan

\section{KESIMPULAN}

Berdasarkan hasil dan pembahasan terkait penerapan Community Based Tourism (CBT) dalam pengembangan desa wisata di Desa Sekapuk Kecamatan Ujungpangkah Kabupaten Gresik, maka penulis dapat menarik kesimpulan sebagai berikut:

1. Pada tahap perencanaan masyarakat belum diikutsertakan secara aktif sesuai dengan prinsip penerapan CBT yang ada, Masyarakat menjadi subjek pendukung dalam mengembangkan wisata di Desa Sekapuk karena segala arahan dan keputusan penuh berada di Kepala Desa Sekapuk.

2. Pada tahap implementasi masyarakat sudah diikutsertakan secara keseluruhan. Terdapat pembagian kerja antara pemerintah desa, Pengelola BUMDesa, serta masyarakat secara keseluruhan. Masyarakat memiliki kepemilikan dalam wisata tersebut berbentuk obligasi saham, serta masyarakat diikutkan dalam evaluasi kinerja setiap bulannya. Kemudian peran masyarakat dalam pelaksanaan pengembangan wisata 
juga terlibat melalui kerja bakti yang berdasarkan informasi dan arahan dari rt dan rw setempat.

3. Pada tahap dampak dan manfaat, sudah diterapkan dengan baik dan keseluruhan. Hal ini dapat dilihat bahwa dampak yang diterima masyarakat desa sekapuk sudah sigmifikan, bertambahnya lapangan pekerjaan pasca pengembangan wisata, serta timbulnya pendapatan masyarakat lokal di desa Sekapuk.

4. Penerapan Community Based Tourism (CBT) dalam pengembangan desa wisata di Desa Sekapuk masih belum diterapkan dengan maksimal, dalam sebagian tahap masyarakat belum berperan secara aktif didalamnya. Hal ini diperlukan perbaikan atau agenda-agenda pendukung dalam memperbanyak peran masyarakat seperti pengadaan workshop atau pelatihan, melakukan rapat besar bersama pemilik saham secara rutin, serta memperbanyak sistem pengaduan atau pemberian saran terhadap pengembangan wisata di Desa Sekapuk. Sehingga masyarakat bisa memberikan perannya dan sarannya dalam perencanaan pengembangan wisata kedepannya

\section{REFERENSI}

Ahsani, R. D. P., Suyaningsih, O., Ma'rifah, N., \& Aerani, E. (2013). Penerapan Konsep Community Based Tourism (Cbt) Di Desa Wisata Candirejo Borobudur Mewujudkan Kemandirian Desa. Journal of Chemical Information and Modeling, 53(9), 1689-1699.

Elfianita, E. (2016). Pengembangan Pariwisata Berbasis Community Based Tourism (CBT) Di Desa Wisata Limbasari Kecamatan Bobotsari, Kabupaten Purbalingga. Jurnal Elektronik Mahasiswa Pendidikan Luar Sekolah, 5(3), 1-11.

Lestari, T. P., Sunarti, \& Hakim. (2019). Pengembangan Pariwisata Dengan Konsep Community Based Tourism Di Boon Pring, Desa Sanankerto, Kecamatan Turen, Kabupaten Malang. Jurnal Administrasi Bisnis (JAB) Universitas Brawijaya, 69(1), 12. http://webcache.googleusercontent.com/search?q=cache:WGN4z28qTqlJ:administrasi bisnis.studentjournal.ub.ac.id/index.php/jab/article/download/2802/3188+\&cd=1\&hl=id $\& c t=c l n k \& g l=i d \& c l i e n t=$ firefox-b-d

Muhammad Elwan, L. O. (2019). PROBLEM BIROKRASI DALAM MENINGKATAN PELAYANAN PUBLIK PADA SEKRETARIAT DAERAH KABUPATEN MUNA. Journal Publicuho. https://doi.org/10.35817/jpu.v2i2.7223

Pantiyasa, I. W. (2018). Pengembangan Pariwisata Berbasis Masyarakat (Community Based Tourism) dalam Pemberdayaan Masyarakat (Studi Kasus di Desa Bedulu, Blah Batuh, Gianyar). Jurnal Ilmiah Hospitality Management, 1 (2).

Prabowo, S., Hamid, D., \& Prasetya, A. (2016). Analisis Partisipasi Masyarakat Dalam Pengembangan Desa Wisata (Studi Pada Desa Pujonkidul Kecamatan Pujon Kabupaten Malang). Jurnal Administrasi Bisnis S1 Universitas Brawijaya, 33(2), 18-24.

Purmada, D., Wilopo, W., \& Hakim, L. (2016). PENGELOLAAN DESA WISATA DALAM PERSPEKTIF COMMUNITY BASED TOURISM (Studi Kasus pada Desa Wisata Gubugklakah, Kecamatan Poncokusumo, Kabupaten Malang). Jurnal Administrasi Bisnis S1 Universitas Brawijaya, $32(2), 15-22$. 


\section{Journal Publicuho}

ISSN2621-1351 (online), ISSN 2685-0729 (print)

Volume 4 Number 2 (May-July), (2021)pp. 591-601

Accredited SINTA SK.NOMOR 28/E/KPT/2019

Open Access at:http://ojs.uho.ac.id/index.php/PUBLICUHO/index DOI: 10.35817/jpu.v4i2.18232

Quynh. (2020). Community-Based Tourism and Destination Attractiveness: From Theory to Practice. Journal of Tourism, Hospitality and Sports, 49.

Rahmi, S. A. (2016). PEMBANGUNAN PARIWISATA DALAM PERSPEKTIF KEARIFAN LOKAL. JUrnal Reformasi, 6(1).

Satrio, D., \& Sabana, C. (2018). Pengembangan Community Based Tourism Sebagai Strategi Pemberdayaan Ekonomi Masyarakat. Jurnal PENA, 32 (1).

Sugiyono. (2018). Metode Penelitian Kuantitatif dan Kualitatif R\&G. Alfabeta.

Supriadin, R., Alam, S., \& Elwan, L. O. M. (2020). IMPLEMENTASI PERATURAN WALIKOTA KENDARI NOMOR 13 TAHUN 2008 TENTANG PENATAAN PEDAGANG KAKI LIMA DI KOTA KENDARI. Journal Publicuho. https://doi.org/10.35817/jpu.v3i1.11506

Undang-Undang Nomor 25 Tahun 2000 Tentang Pembangunan Nasional. 